研 究 室 紹介

\author{
神戸大学大学院 \\ 人間発達環境学研究科 \\ 都市環境システム研究室
}

\section{Urban Environmental System Laboratory, Graduate School of Human Development and Environment, Kobe University}

\section{1.はじめに}

神戸大学大学院人間発達環境学研究科は、1949年に兵 庫師範学校と兵庫青年師範学校を統合して設置された教育 学部を出発点としています。当研究科は、「人間の発達及 びそれを支える環境を対象とした発達科学に関する卓越し た教育研究を実施すること」をミッションとして、2007 年に設置されました。また、兼務先である国際人間科学部 は、教育学部を改組して設置された発達科学部と国際文化 学部を再編する形で、2017年に設置されました。

人間発達環境学研究科は教育学部が前身であることを背 景として、理学、工学、経済学、教育学、心理学、芸術な どの様々な専門分野を持ち、文化系／理科系、そして文理 融合の観点から多様な研究に専念されている多くの教員が います。一研究科だけで、持続可能な開発目標 (SDGs) の 17 目標の全てに関わる教員が揃っていると言っても、 過言ではないでしょう。人間発達環境学研究科は環境問題 だけでなく、いわゆる環境を様々な側面から学ぶことがで き、持続可能な社会とは何か？という本質的な問いについ て、自分で考え解決策を導き出していくことができる人材 を養成しています。人間発達環境学研究科では、一般・留 学生のほか、社会人も募集しています。興味がありました ら、是非ホームページ (http://www.h.kobe-u.ac.jp/ja/ node/8）を御覧ください。国際人間科学部のホームペー ジ（https://www.fgh.kobe-u.ac.jp/ja/admissions）も合わ せてどうぞ。

人間発達環境学研究科は、六甲山の麓に位置する鶴甲第 2 キャンパスにあります。本キャンパスの標高は $210 \mathrm{~m} て ゙ 、$ 神戸大学で最も標高が高いところにあるキャンパスです。 本キャンパスに到着するまでの登山は大変ですが（バスに 乗れば楽ちんです)、キャンパスの建物内から眺める神戸 市や大阪湾の景色は格別です。ぜひ神戸大学にお越しの際 は、本キャンパスにもお立ち寄りください。

\section{2. 研究室について}

\section{1 研究室の概要}

都市を構成する住宅やインフラは、元々は資源です。都
市を構築し、維持していくためには資源やエネルギーが必 要です。私達の身の回りにある家電や衣類なども、本を正 せば資源です。私たちの生活は膨大な資源やエネルギーが 必要ですが、これが結果として環境に悪影響を及ぼしてい ます。本研究室は、都市を一つのシステムとして捉え、物 質フロー分析、LCA ライフサイクル思考を用いて、資 源やエネルギーの消費量の抑制や環境負荷の削減に貢献で きる、持続可能な都市を構築することを研究目標としてい ます。

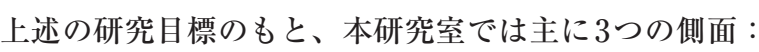
(1)マクロ (国・世界) 〜メゾ (都市) 〜ミクロ (家庭) レ ベルでの資源循環構造の把握、(2)ごみ処理や再生可能エネ ルギーなどに係る地域施策の環境面・経済面・社会面の評 価、(3)地域施策に対する住民の受容性の評価や消費者行動 の評価、について研究しています。当研究室の研究キー ワードは、ごみ処理、再生可能エネルギー、消費者行動・ ライフスタイル、防災・減災、高齢者、貧困などです。こ れらのキーワードからわかるように、多様な側面から持続 可能な都市のあり方を追求していることが本研究室の特徵 です。LCAに関連する手法に加えて、シミュレーション などの工学的手法、アンケートや統計処理などの社会科学 的手法、環境経済学の手法などを用いて、文理融合型の視 点から研究を行っているのも本研究室の特徵です。

本研究室は、2021年 8 月現在、大学院生と学部生合わせ て11名の学生が所属しています。現在はコロナ禍により オンラインでのゼミに留まっていますが、コロナ禍前は施 設見学やゼミ旅行、飲み会を定期的に行っていました（図 1)。兼務先の国際人間科学部環境共生学科は、文化系 理科系の入試が行われているという特徵がありまして、研 究室にも文化系／理科系の学生がそれぞれ所属しています。 次節では、研究室で主に行っている研究テーマの概要を 紹介します。

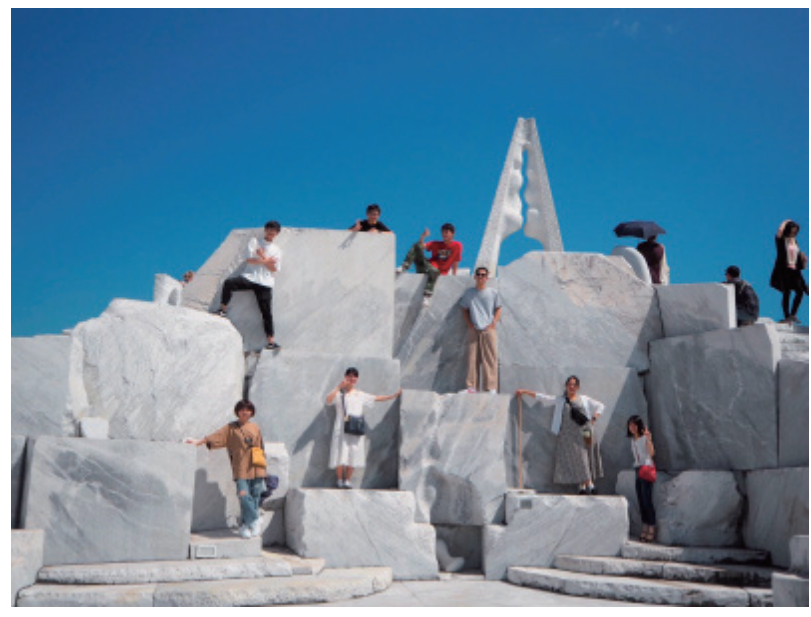

図 1 ゼミ旅行(愛媛県瀬戸田町、未来心の丘にて) 


\section{2 現在の主な研究テーマ \\ 2.2 .1 再生可能エネルギー}

都市や地域に再生可能エネルギーを導入することによる 環境負荷削減効果を明らかにするだけでなく、経済性や社 会面（地域活性化や雇用創出など）への効果や課題なども 明らかにすることで、再生可能エネルギーに基づく都市シ ステムの構築の是非やそのあり方を検討しています。これ までに、淡路島に賦存する再生可能エネルギーのみを用い た電力の地域自立の可能性や、神戸市を代表する都市近郊 山である六甲山の木質バイオマスをエネルギー利用した場 合の市民や観光客の受容性などを分析してきました。

近年は、山林を伐採して設置されるメガソーラー発電所 を事例として、太陽光発電の運用による地球温暖化対策へ の貢献といったメリットと、伐採に伴う生物多様性の㳖失 や災害リスクの増加などといったデメリットを考慮した多 基準分析を実施するための方法論を提案しています（Mori and Tabata 2020)。太陽光発電は全国各地で設置が進ん でいますが、自然災害に伴うパネル破損といった二次被害 の発生や生物多様性・景観の䚻失といった問題が注目され ています。太陽光発電所設置の検討に係るステークホル ダー間での合意形成において、本研究で提案したような方 法論が役に立つと考えています。

\subsection{2 災害廃棄物}

私は、大学生の頃から廃裹物処理に関する研究を行って きました。災害廃裹物に関わるようになったのは2011年 の東日本大震災がきっかけでして、これまでの知見を防 災・減災対策に活かしたいという考えから研究をはじめま した。研究では、家庭のストック（住宅、車、家財など） をもとに、地震や水害が発生した場合の災害廃棄物発生量 を推計する仕組みを考案してきました。また、LCAに地 理情報システムや最適化モデルなどを組み合わせて、災害 廃棄物の撤去〜処理に係るライフサイクルでの環境負荷や コストを算出するための方法論を提案してきました。これ らの経験をもとに、自治体の災害廃裹物処理計画の策定に 係る助言などを行っています。

また、平時に不要なストックの削減、住宅の耐震補強や 家財の地震対策などが、災害時の災害廃裹物の発生量抑制 に貢献することに着目し、対策実施による発生抑制効果の 測定も行っています。図2は、地震により堤防が破壊され る場合と破壊されない場合での災害廃裹物発生量の違いを シミュレーションした結果です（Tabata et al. 2019）。地 震後でも堤防の健全性が守られることは、生命や財産が保 全されるだけでなく、災害廃棄物の発生抑制にも大きな効 果があると言えます。

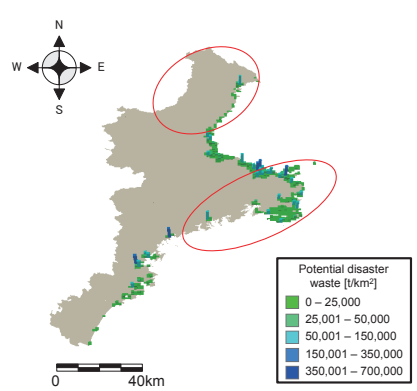
ない場合 (a)地震でも堤防が破壊され

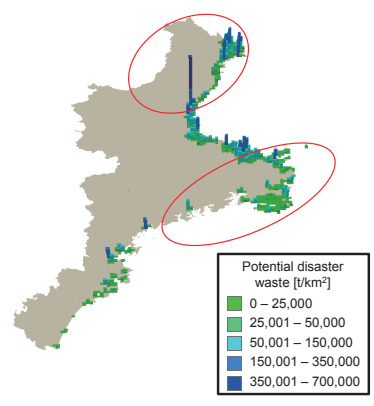

(b)地震で堤防が破壊された 場合
図2 災害廃棄物の発生抑制効果のシミュレーション (Tabata et al. 2019)

\subsection{3 高齢者と環境・エネルギーとの関わり}

神戸大学に着任して以降、生活に関わる研究・教育に携 わることになりました。その中で、高齢者が現在以上に増 加することで、自治体が提供しているごみ処理などの仕組 みが立ち行かなくなる可能性があるのではないかと考えま した。これをきっかけとして、高齢者と環境・エネルギー との関わりに着目した研究を行っています。例えば、高齢 者は加齢に伴い認知機能や体力が衰えていきます。これが 結果として、ごみ出しやごみ分別にどのような影響を及ぼ す可能性があるかを検討しました（田畑ら 2016）。

また、高齢者は在宅時間が長く、これが家庭内のエネル ギー消費量の増加にも影響します。これを勘案して、高齢 者世帯のエネルギー消費量を推計するだけでなく、エネル ギーに関連するコストが高齢者世帯の家計をどのくらい圧 迫している可能性があるかということも研究しています。

\subsection{SDGsに関わる研究}

前述したとおり、人間発達環境学研究科ではSDGsの 17 目標に関係する教員が揃っています。私はこの恵まれた環 境の中で、研究科内での共同研究を行っています。例えば、 高齢者のごみ出し、ごみ分別に関する研究は、老年学を専 門とする教員との共同研究です。また、六甲山における地 域活性化や環境保全などを意図する森林管理を推進するこ とで、SDGsのどの目標を達成可能かについても検討して います（田畑ら 2021）。私は専門柄、森林管理と言うと環 境や森林などに関する目標が関連すると考えますが、他の 専門分野の教員は貧困や教育、働きがいなどの目標が関連 すると考えます。これは目からウロコで、このような考え 方を取り入れて新たな知見を見出していくことが、文理融 合型の研究の醍醐味だと考えています。

上記以外にも、環境未来都市構想に選定された都市・地 域を対象に、環境・経済・社会の側面から選定されたこと の効果や課題を考察すると言った、政策評価に係る研究も 行っています（豊成、田畑 2020）。 


\section{3. おわりに}

私が神戸大学に着任したのは 2010 年 10 月です。当時は 最年少に近いような若手の教員でしたが、いつの間にか年 下の教員が増えて、中堅の立場になってしまいました。と はいえ、いつまでも初心は忘れないようにしたいです。 2015年 3 月に神戸大学六甲台第 1 キャンパスで開催された 第 10 回日本LCA学会研究発表会では、副実行委員長を担 当しました。とても大変でしたが、今となっては良い思い 出です。

上述した研究紹介は、本研究室で行っている研究のほん の一例です。これ以外にも多くの研究を行っていますので、 興味がある方は本研究室のホームページを御覧ください。

\section{参照文献}

Mori K., Tabata T. (2020), Comprehensive evaluation of photovoltaic solar plants vs. natural ecosystems in green conflict situations, Energies, MDPIホームペー ジ,入手先 <https://www.mdpi.com/19961073/13/23/6224>, (参照 2021-08-09)

Tabata T., Onishi A., Saeki T., Tsai P. (2019), Earthquake disaster waste management reviews: prediction, treatment, recycling, and prevention, International Journal of Disaster Risk Reduction, ScienceDirectホームページ，入手先 <https://www. sciencedirect.com/science/article/abs/pii/
S2212420918314481>, (参照 2021-08-09)

田畑智博, 小田実紀, 宮本一毅, 蔡 佩宜, 片桐恵子 (2016), 超高齢社会に対応した廃裹物処理システムのあり方 に関する考察, 日本LCA学会誌, J-STAGEホームペー ジ, 入手先 <https://www.jstage.jst.go.jp/article/ lca/12/4/12_243/_article/-char/ja/>，（参照 2021-0809)

田畑智博, 周 俊男, 大野朋子, 村山留美子, 井口克郎, 片桐恵 子 (2021), SDGsのローカライゼーションに関する考 え方の提案 : 六甲山の森林管理と地域活性化を事例 として, 日本森林学会誌, J-STAGEホームページ, 入手 先 <https://www.jstage.jst.go.jp/article/ jjfs/103/1/103_33/_article/-char/ja/>，（参照 202108-09)

豊成春子, 田畑智博 $(2020)$,「環境未来都市」構想に関する 取組の効果と課題に関する考察, 環境科学会誌, J-STAGEホームページ, 入手先 <https://www.jstage. jst.go.jp/article/sesj/33/6/33_330602/_article/-char/ ja>, （参照 2021-08-09）

\section{連絡先}

神戸大学大学院 人間発達環境学研究科 准教授 田畑 智博

E-mail: tabata@people.kobe-u.ac.jp

URL: http://www2.kobe-u.ac.jp/ ttabata/ 